\title{
ROLA I FUNKCJONOWANIE ASYSTENTÓW ZDROWIENIA (EX-IN) W ŚRODOWISKOWYM MODELU OPIEKI PSYCHIATRYCZNEJ
}

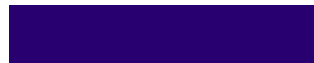 \\ MONIKA BARTOSIEWICZ-NIZIOŁEK \\ Polskie Towarzystwo Ewaluacyjne \\ SONIA KACZMARCZYK-PARTYKA \\ Fundacja Wspierania Rozwoju Społecznego „Leonardo" \\ BARTOSZ H. OLSZEWSKI* \\ Uniwersytet Kardynała Stefana Wyszyńskiego w Warszawie \\ MAGDA OSTROWSKA \\ Uniwersytet Kardynała Stefana Wyszyńskiego w Warszawie
}

\section{STRESZCZENIE}

Asystenci zdrowienia są nową rolą wśród zawodów pomocowych z zakresu ochrony zdrowia psychicznego w Polsce. Powstanie tej grupy związane jest $\mathrm{z}$ rozwojem idei odchodzenia od hospitalizacji osób $\mathrm{z}$ doświadczeniem kryzysu psychicznego w dużych szpitalnych ośrodkach na rzecz przeprowadzania procesu leczenia w środowisku lokalnym. Główna funkcja asystentów zdrowienia koncentruje się na towarzyszeniu osobom zmagającym się z kryzysem psychicznym $\mathrm{w}$ procesie ich zdrowienia. Asystenci, którzy są członkami zespołów terapeutycznych, pełnią unikalną rolę, zaspokajając potrzeby osób $\mathrm{z}$ doświadczeniem kryzysu psychicznego i ich bliskich. Rola ta polega na poznawaniu, zrozumieniu, wzmacnianiu, dawaniu nadziei na wyzdrowienie i przekazywaniu osobom w kryzysie praktycznej wiedzy dotyczącej tego procesu oraz dostępnych metod leczenia. $W$ artykule zarysowano koncepcję asystentów zdrowienia jako wzajemnego wsparcia (peer support) oraz ideę ich funkcjonowania w środowiskowym modelu opieki psychiatrycznej. Opisano proces szkolenia asystentów zdrowienia, ramy kwalifikacji oraz ich działalność w środowisku lokalnym, sieciach społecznych oraz ze specjalistami.

ASYSTENCI ZDROWIENIA
ZDROWIE PSYCHICZNE
OCHRONA ZDROWIA PSYCHICZNEGO
KRYZYS ZDROWIA PSYCHICZNEGO
PEER SUPPORT
ŚRODOWISKOWY MODEL OPIEKI
PSYCHIATRYCZNEJ

岂

11 RAMY KWALIFIKACJ ORAZ REGULACJE PRAWNE

12 PIERWSZE DOŚWIADCZENIA Z WPROWADZANIEM ASYSTENTÓW ZDROWIENIA W POLSCE

16 WNIOSKIIREKOMENDACJE

18 BIBLIOGRAFIA 


\title{
THE ROLE AND FUNCTIONING OF MENTAL HEALTH RECOVERY ASSISTANTS (EX-IN) IN THE COMMUNITY MODEL OF PSYCHIATRIC CARE
}

\begin{abstract}
Recovery assistants are a new role among mental health care professions in Poland. The emergence of this group is related to the development of the idea of abandoning hospitalization of people experiencing mental crisis in large hospital centers in favor of carrying out the treatment process in the local environment. The main function of recovery assistants is to accompany people struggling with a mental crisis in their recovery process. Assistants who are members of therapeutic teams play a unique role in meeting the needs of people experiencing a mental crisis and their relatives. This role is to know, understand, strengthen, give hope for recovery and provide people in crisis with practical knowledge about this process and available treatments. The article outlines the concepts of recovery assistants as peer support and the idea of their functioning in the environmental model of psychiatric care. The process of training recovery assistants, the qualification framework and their activities in the local community, social networks and with specialists are described.
\end{abstract}

\section{KEYWORDS:}

mental health crisis, peer support, community model of psychiatric care 
systenci zdrowienia to nowa rola zawodów pomocowych z zakresu ochrony zdrowia psychicznego w Polsce. Idea funkcjonowania asystentów zdrowienia w ostatnich latach znacząco zyskała na popularności, wpisując się w trwającą reformę opieki psychiatrycznej poprzez uwzględnienie asystentów zdrowienia w rozporządzeniu Ministra Zdrowia $\mathrm{z}$ dnia 27 kwietnia 2018 roku w sprawie programu pilotażowego w centrach zdrowia psychicznego (Dz. U. 2018 poz. 852) jako personelu niezbędnego do zatrudnienia w tychże podmiotach. Rola asystenta zdrowienia wpisuje się w międzynarodowy kontekst wzajemnego wsparcia (peer support), opierający się na przekonaniu, że osoby, które doświadczyły i przetrwały różnego rodzaju trudności są w stanie zaoferować wsparcie, inspirację oraz nadzieję innym osobom znajdującym się w podobnej sytuacji (Davidson, Chinman, Sells, Rowe, 2006). Trudności te obejmują przede wszystkim choroby psychiczne i uzależnienia, niepełnosprawności, traumy, choroby nowotworowe oraz problemy wychowawcze z młodzieżą. Dla osób, które przeżyły poważny kryzys psychiczny, wspólne doświadczenia dotyczą głównie radzenia sobie $z$ ostrymi epizodami choroby, konsekwencjami życia ze stygmatem osoby z zaburzeniami psychicznymi, a także kontaktami z systemem opieki zdrowotnej.

Nowo powstała rola asystenta zdrowienia nie mogła trafić na lepszy moment w rozwoju psychiatrii środowiskowej w Polsce. Idea odchodzenia od hospitalizacji osób z doświadczeniem kryzysu psychicznego w dużych szpitalnych ośrodkach jest rozwijana w Europie od lat 60. XX wieku, a wiele krajów europejskich, w tym Polska, inspirują się przeprowadzoną we Włoszech reformą psychiatrii. Twórcy włoskiej reformy uważają, że możliwe jest niemal całkowite zastąpienie szpitali psychiatrycznych alternatywnymi metodami opieki (Mokrzycka-Markowska, Drozdowicz, Nasierowski, 2015). Od kilku lat Polska jest beneficjentem środków Europejskiego Funduszu Społecznego przeznaczonych na deinstytucjonalizację usług psychiatrycznych. Równolegle wprowadzana jest reforma Ministerstwa Zdrowia polegająca na wdrażaniu ogólnodostępnej psychiatrycznej opieki środowiskowej, oferowanej blisko miejsca zamieszkania w formie Centrów Zdrowia Psychicznego (CZP). Kumulacja powyższych inicjatyw stanowi idealne miejsce do rozwijania roli asystenta zdrowienia, ponieważ wzajemne wsparcie w założeniach było alternatywą dla standardowej opieki psychiatrycznej i lepiej funkcjonuje w strukturach środowiskowych, które są mniej zhierarchizowane niż szpitale psychiatryczne.

$\mathrm{Na}$ etapie opracowywania standardów zawodowych i szkoleniowych dla osób oferujących wzajemne wsparcie w latach 2005-2007 specjaliści w zakresie zdrowia psychicznego, przedstawiciele osób z doświadczeniem kryzysu psychicznego i trenerzy z 10 organizacji (z Niemiec, Holandii, Szwecji, Norwegii, Wielkiej Brytanii i Słowenii) zrealizowali projekt pilotażowy finansowany w ramach europejskiego programu Leonardo da Vinci ${ }^{1}$. Celem projektu było sformułowanie i przetestowanie programu dla osób z doświadczeniem kryzysu psychicznego. Program miał umożliwić uzyskanie kwalifikacji do pracy w charakterze ekspertów przez doświadczenie (Ex-In - Experienced Involvement) w ramach usług ochrony zdrowia psychicznego i edukacji. Wypracowany w ramach projektu program szkoleniowy jest od ponad 10 lat prowadzony w krajach Europy Zachodniej - w szczególności w Niemczech (Utschakowski, 2012).

Efekty powyższego projektu były bezpośrednią inspiracją do wprowadzenia w Polsce wzajemnego wsparcia. W latach 2016-2019 w ramach projektu pn. Nowy Zawód: Ekspert przez Doświadczenie ("Ex-In”) wdrażanego przez Fundacje „Leonardo”, Polski Instytut Otwartego Dialogu, Uniwersytet Kardynała Stefana Wyszyńskiego w Warszawie oraz Stowarzyszenie „Feniks” podjęto próbę przełożenia modelu niemieckiego na warunki

${ }^{1}$ https://ex-in.de/ex-in-europa/ (dostęp: 22.12.2021). 
krajowe $^{2}$. Przedsięwzięcie to było wspólfinansowane ze środków Unii Europejskiej w ramach Programu Operacyjnego Wiedza Edukacja Rozwój i zostało skierowane do osób w wieku od 18 do 67 lat zamieszkałych na terenie czterech województw: małopolskiego, dolnośląskiego, mazowieckiego i zachodniopomorskiego. W szkoleniach tych wzięło udział 100 uczestników, spośród których 60 odbyło następnie kilkumiesięczne staże w różnego rodzaju placówkach ochrony zdrowia psychicznego: na oddziałach psychiatrycznych szpitali, w zespołach leczenia środowiskowego, środowiskowych domach samopomocy, a także w organizacjach pozarządowych. W rezultacie około 20 osób zostało zatrudnionych w roli asystentów zdrowienia (Kaczmarczyk i in., 2019). W ramach tego projektu po raz pierwszy użyto nazwy „asystent zdrowienia” do opisu przeszkolonej osoby z osobistym doświadczeniem kryzysu psychicznego, chociaż nazwa ta jest stosowana wymiennie $\mathrm{z}$,ekspertem przez doświadczenie” lub „Ex-In”. Końcowy raport z realizacji projektu zawiera całościowy program szkolenia, standardy dotyczące rekrutacji asystentów zdrowienia, kodeks etyczny i zalecenia dla instytucji przyjmującej asystentów zdrowienia. Absolwenci szkoleń założyli w 2019 roku pierwsze ogólnopolskie Stowarzyszenie Asystentów Zdrowienia.

\section{ASYSTENCI ZDROWIENIA JAKO EKSPERCI PRZEZ DOŚWIADCZENIE}

Wypracowana na polskim gruncie definicja asystentów zdrowienia podąża $\mathrm{w}$ ślad za międzynarodowymi definicjami (Utschakowski, 2012). Mianem asystentów zdrowienia jako ekspertów przez doświadczenie w ochronie zdrowia określane są osoby, które aktywnie doświadczyły choroby, niepełnosprawności i/lub problemów ze zdrowiem psychicznym, w konsekwencji czego zyskały pogłębioną wiedzę i znajomość kontekstów społeczno-kulturowo-instytucjonalnych, w których trudności w ww. zakresie nabierają szczególnego znaczenia. Asystenci zdrowienia potrafią wykorzystać własne doświadczenia kryzysu psychicznego we wspieraniu innych osób, które borykają się z podobnymi trudnościami.

Tak szeroka definicja nie jest jednak wystarczająca do ukonstytuowania roli asystentów zdrowienia w kontekście zawodowym ochrony zdrowia psychicznego. Środowisko próbuje wypracować jednolite standardy w tym zakresie, ale wciąż nie osiągnięto konsensusu. Wątpliwości dotyczą warunków osobowościowych, jakie powinna spełniać osoba ubiegająca się o status asystenta zdrowienia, oceny umiejętności autorefleksji w zakresie własnych doświadczeń chorobowych, zakresu programowego szkoleń i ich wymiaru godzinowego, a także oceny kompetencji Ex-In oraz ich miejsca w zespołach terapeutycznych. Jednym z kroków podjętych w celu określenia ram i wymagań wobec asystentów zdrowienia jest próba włączenia opisu ich kwalifikacji do ogólnopolskiego Zintegrowanego Systemu Kwalifikacji.

Początki zrzeszania się osób o podobnych doświadczeniach w zakresie zdrowia psychicznego sięgają XIX wieku, czego przykładem może być Alleged Lunatics' Friends Society, stowarzyszenie działające w latach 1845-1863 w Wielkiej Brytanii na rzecz lepszej ochrony przed przymusowym zamknięciem i niewłaściwym traktowaniem pacjentów przebywających w zakładach psychiatrycznych (Basset, Faulkner, Repper, Stamou, 2010). Bardziej aktualnym przykładem są ruchy działające w Stanach Zjednoczonych w latach 70. XX wieku zrzeszające byłych pacjentów szpitali psychiatrycznych, współdzielących doświadczenia dyskryminacji i stygmatyzacji, lobbujące na rzecz reform w ochronie zdrowia psychicznego. Powyższe grupy w dużej mierze opierały się na walce o prawa pacjentów, ale częściowo gwarantowały swoim członkom wzajemne wsparcie i położyły podwaliny pod ruchy samopomocowe. Przykładem organizacji funkcjonującej już od lat 30. XX wieku oraz

2 http://fundacja-leonardo.pl/nowy-zawod/ (dostęp: 22.12.2021). 
bazującej wyłącznie na wzajemnym wsparciu są Anonimowi Alkoholicy, których członkowie wykorzystują osobistą wiedzę i doświadczenia radzenia sobie z problemem alkoholowym, aby pomagać sobie nawzajem (Zadrożna, 2019). Lata 90. XX wieku przyniosły bardziej sformalizowane próby włączenia osób z przewlekłymi chorobami psychicznymi do systemu ochrony zdrowia psychicznego. W 1991 roku w Denver przeszkolono 25 osób $\mathrm{z}$ doświadczeniem choroby psychicznej do zatrudnienia w roli pomocy kierownika przypadku (case manager) w ramach projektu rehabilitacji psychiatrycznej (Sherman, Porter 1991). Po dwóch latach w grupie 15 wciąż pracujących osób zdarzyły się jedyne 2 dni hospitalizacji psychiatrycznej od momentu ukończenia szkolenia. Obecnie w większości krajów zachodnich włączanie pacjentów (nazywanych użytkownikami ochrony zdrowia psychicznego) w planowanie, organizację i ewaluację opieki psychiatrycznej jest standardem (Cechnicki, Liberadzka, 2012).

Aktualnie w ramach wzajemnego wsparcia wyodrębnia się kilka kategorii (Solomon, 2004):

1. Grupy samopomocowe - to najstarsza forma wzajemnego wsparcia, składają się z osób o podobnych doświadczeniach działających wolontarystycznie. Obecnie niemal dla każdej trudności psychologicznej można odnaleźć grupę samopomocy. W przeciwieństwie do grup wsparcia nie są one prowadzone przez specjalistę. Grupy samopomocowe funkcjonują $\mathrm{z}$ powodzeniem $\mathrm{w}$ Internecie, gwarantując uczestnikom pewien stopień anonimowości. W Polsce samoorganizowanie i oddolne działania osób chorujących psychicznie nadal nie są popularne, chociaż powoli przyrasta liczba grup samopomocowych, takich jak Grupa Wsparcia Osób z Doświadczeniem Kryzysu Psychicznego TROP (Bronowski, Chotkowska, Bednarzak, 2016).

2. Usługi świadczone przez osoby $\mathrm{z}$ doświadczeniem kryzysu psychicznego (peer run or operated services) - obejmują przedsięwzięcia i organizacje tworzone, obsługiwane i administrowane w zdecydowanej większości przez Ex-In, które działają na rzecz zdrowienia. Przykładem takich usług są kryzysowe miejsca noclegowe (peer respite), obsługiwane w całości przez personel z własnym doświadczeniem poważnego kryzysu (People USA's Rose Houses czy Red Umbrella Project w Nowym Jorku) ${ }^{3}$. W Polsce działa wiele organizacji prowadzonych przez pacjentów ze schorzeniami somatycznymi, natomiast organizacje świadczące usługi na rzecz osób z chorobami i zaburzeniami psychicznymi są na wstępnym etapie rozwoju (przykładami mogą być: Stowarzyszenie Młodzieży i Osób z Problemami Psychicznymi, Ich Rodzin i Przyjaciół POMOST lub Stowarzyszenie Pacjentów „Otwórzcie Drzwi” z Krakowa).

3. Indywidualni pracownicy wzajemnego wsparcia - są to osoby po kryzysach psychicznych zatrudnione na samodzielnych stanowiskach w placówkach związanych $\mathrm{z}$ ochroną zdrowia psychicznego, którzy mogą pracować w tradycyjnych strukturach lub działać środowiskowo. Zazwyczaj takie zatrudnienie wiąże się $\mathrm{z}$ otwartością oraz identyfikowaniem się jako osoba z doświadczeniem choroby, zaburzeń, czy kryzysów psychicznych. Do tej kategorii należy rola asystenta zdrowienia.

Szacunkowa liczba aktywnie działających osób po kryzysach psychicznych (peer support staff) w jednostkach ochrony zdrowia psychicznego sięga 10 tys. osób w samych Stanach Zjednoczonych (Davidson, Bellamy, Guy, Miller, 2012). Równolegle rośnie liczba badań naukowych skupiających się na skuteczności wzajemnego wsparcia, efektywności kosztowej takich usług oraz ustaleniu standardów zawodowych. Większość wyników badań wskazuje, że usługi wzajemnego wsparcia są związane z szeregiem pozytywnych rezultatów dla użytkowników świadczeń psychiatrycznych, takich jak: powrót do życia społecznego, zmniejszenie liczby hospitalizacji, poprawa jakości życia, większa akceptacja choroby, lepsze

${ }^{3}$ https://www.redumbrellafund.org (dostęp: 22.12.2021) oraz https://www.peerrespite.com/guidebook (dostęp: 22.12.2021). 
funkcjonowanie społeczne i częstsze przestrzeganie zaleceń lekarskich dotyczących procesu leczenia (Crane, Lepicki, Knudsen, 2016). Wzajemne wsparcie wiąże się także z większym zaufaniem użytkowników usług do personelu medycznego i wzrostem zaangażowania we własny proces leczenia (Pickett i in., 2012). Osoby, które mają złe doświadczenia z tradycyjnymi strukturami systemu ochrony zdrowia, chętniej korzystają z usług pracownika z doświadczeniem kryzysu. Jednocześnie sami pracownicy wzajemnego wsparcia deklarują pozytywne korzyści funkcjonowania w tej roli, przede wszystkim wymieniając: rozwój osobisty, samopoznanie, wzrost wiary we własną skuteczność, wzmocnienie (empowerment), poprawę samooceny, lepsze radzenie sobie $\mathrm{z}$ własną diagnozą, budowanie umiejętności zawodowych, lepszą organizację czasu oraz rozwijanie sieci wsparcia (Salzer, 1997; Salzer, Shear, 2002). Praca w roli osoby oferującej wzajemne wsparcie jest również związana ze zwiększeniem satysfakcji życiowej (Mowbray, Moxley, Collins, 1998).

Według Delman i Vorhies Klodnick (2017) niepowtarzalna, w kontekście innych zawodów pomocowych z obszaru zdrowia psychicznego, charakterystyka oraz wartość roli osoby oferującej wzajemne wsparcie - asystenta zdrowienia opiera się na czterech filarach:

1. Strategiczne wykorzystanie wiedzy płynącej z własnych doświadczeń kryzysu psychicznego i procesu zdrowienia.

2. Pełnienie funkcji wzoru do naśladowania. Asystenci zdrowienia są przykładem, że zdrowienie i rehabilitacja zawodowa są możliwe. Działają oni wbrew stereotypom i dają ludziom w kryzysach nadzieję na możliwość powrotu do pełnego, satysfakcjonującego życia.

3. Działania na rzecz osób z doświadczeniem kryzysu psychicznego. Asystenci zdrowienia przekazują perspektywę tych osób zespołowi terapeutycznemu, angażują je do aktywnego udziału w procesie zdrowienia i podejmowania decyzji zdrowotnych oraz pomagają przełamywać bariery pomiędzy tymi osobami a personelem specjalistycznym, wspomagając ich komunikację.

4. Relację opartą na szacunku, empatii, bezwarunkowym pozytywnym podejściu, partnerstwie i wzajemności.

Zasadnicza funkcja asystentów zdrowienia polega na towarzyszeniu osobom zmagającym się z kryzysem psychicznym w procesie ich zdrowienia. Asystenci, którzy są członkami zespołów terapeutycznych, pełnią unikalną rolę, zaspokajając te potrzeby osób z doświadczeniem kryzysu psychicznego i ich bliskich, na które nie mogą odpowiedzieć specjaliści będący „ekspertami przez edukację”. Rola ta polega na poznawaniu, zrozumieniu, wzmacnianiu, dawaniu nadziei na wyzdrowienie i przekazywaniu osobom w kryzysie praktycznej wiedzy dotyczącej tego procesu oraz dostępnych metod leczenia. Asystenci zdrowienia przybliżają specjalistom perspektywę osoby będącej w kryzysie, jej cele, potrzeby, pragnienia oraz różnorodne uwarunkowania, pomagając im „dostrzec człowieka, a nie tylko chorobę". Asystenci skupiają się na wspieraniu osób w kryzysie, ale nie ich wyręczaniu, tworząc sprzyjające warunki do jak najpełniejszego wykorzystania potencjału tych osób. Aktywizują i motywują je do działania oraz samodzielności, wzmacniają w podejmowaniu decyzji, a także wspierają w powrocie lub podejmowaniu nowych ról społecznych i zawodowych. Służąc własnym przykładem pomagają osobom $\mathrm{z}$ trudnościami psychicznymi w świadomym i intencjonalnym dbaniu o zdrowie oraz dążeniu do samostanowienia i samorealizacji. Asystenci zdrowienia, wspierając osoby w kryzysie, mogą odwoływać się nie tylko do swoich przeżyć, ale też doświadczeń innych osób w kryzysie, z którymi zetknęli się w procesie własnego zdrowienia, co zapewnia im wiarygodność, budzi zaufanie i sprawia, że są nie do zastąpienia przez profesjonalistów postrzegających zaburzenia i choroby psychiczne $z$ innej perspektywy niż autopsja.

Asystenci potrafią empatycznie słuchać, wspierać i motywować osoby w kryzysie dzięki odwoływaniu się do własnych doświadczeń. Dają też siłę oraz nadzieję rodzinom i bliskim tych osób poprzez pokazanie, że nawet choroba może stanowić zasób, w oparciu o który 
można budować dalsze życie, a jednocześnie pomagać innym. W przypadku osób w kryzysie, które nie mają wsparcia w rodzinie ani w swoim środowisku, pomoc asystentów zdrowienia jest nieoceniona, szczególnie w sytuacjach kryzysowych, a także kontynuacji procesu zdrowienia w celu wydłużenia remisji oraz uniknięcia szybkiego powrotu do szpitala. Asystenci zdrowienia mogą także współpracować $\mathrm{z}$ rodzinami lub bliskimi osób doświadczających problemów psychicznych, pomagać w odnalezieniu się w systemie ochrony zdrowia oraz - na przykładzie własnej osoby - dawać nadzieję na wyjście z kryzysu i możliwość wykorzystania potencjału tego doświadczenia.

Empatia i zrozumienie, które asystenci zdrowienia okazują osobom w kryzysie, stanowi bazę ich wzajemnych relacji, ale jednocześnie nie należy zapominać o tym, że są oni wrażliwymi osobami, które mogą mieć „kruchą” psychikę, więc nie powinny być nadmiernie obciążane obowiązkami zawodowymi i narażane na sytuacje ekstremalne, z którymi mogą mieć do czynienia zespoły mobilne, jak akty agresji lub próby samobójcze. Współpraca pomiędzy asystentami zdrowienia oraz specjalistami wymaga nie tylko ustalenia jasnych reguł i procedur, które będą respektowane, ale także dużej uważności i wyczucia.W obawie przed powtórnym kryzysem i nawrotami choroby członkowie zespołów mobilnych starają się nie korzystać z pomocy asystentów zdrowienia $\mathrm{w}$ przypadku trudnych i niestabilnych środowisk, natomiast zapraszać ich do współpracy wtedy, gdy osoba w kryzysie jest do tego w pełni gotowa.

Asystenci zdrowienia potrafią też w przystępny sposób wytłumaczyć rodzinie lub bliskim, co przeżywa osoba będąca w kryzysie, jak wygląda problem z jej punktu widzenia, co się z nią dzieje oraz w jaki sposób funkcjonuje w chorobie. Jest to szczególnie istotne, gdy rodzina podejrzewa, że ich krewny symuluje chorobę. Bliski kontakt asystentów zdrowienia $\mathrm{z}$ osobą w kryzysie umożliwia też sygnalizowanie odpowiednio wcześniej niepokojących sytuacji oraz gdy pojawia się zagrożenie pogorszenia jej stanu zdrowia. W takich sytuacjach, po wcześniejszym poinformowaniu właściwych osób, asystenci zdrowienia wycofują się na jakiś czas z realizacji swoich zadań na rzecz tej osoby, aby niepotrzebnie nie narażać na uszczerbek własnego stanu psychicznego.

\section{RAMY KWALIFIKACJI ORAZ REGULACJE PRAWNE}

Aktualnie trwają rozmowy z udziałem Ministerstwa Zdrowia dotyczące ram kwalifikacji asystentów zdrowienia. Opis tych kwalifikacji, jak również systemu certyfikacji asystentów zdrowienia został zgłoszony do Ministerstwa Zdrowia i aktualnie jest procedowany. W dokumencie, który został wypracowany z inicjatywy Fundacji „Leonardo”, zamieszczono wymóg posiadania wykształcenia co najmniej zawodowego (tj. na III poziomie według Polskiej Ramy Kwalifikacji). Zapis ten wskazuje na preferowanie modelu włączającego, mającego na celu przeciwdziałanie zamykania dostępu do zawodu asystenta zdrowienia osobom, które z powodu problemów ze zdrowiem psychicznym nie mogły uzyskać wyższego wykształcenia niż zawodowe. Kolejny wymóg dotyczy przepracowania doświadczenia kryzysu w drodze własnej terapii, która powinna podnieść samoświadomość ekspertów przez doświadczenie i poprawić jakość ich życia. O takiej potrzebie świadczy fakt, że część uczestników szkolenia dla asystentów zdrowienia podjęła psychoterapię w trakcie jego trwania lub niedługo po zakończeniu tego kursu. Psychoterapię można rozpocząć w trakcie szkolenia (wówczas będzie ona stanowiła swego rodzaju ochronę), ponieważ w niektórych przypadkach może nastąpić pogorszenie stanu zdrowia, lub po zakończeniu kursu. W ramach kwalifikacji wpisano jako jeden z wymogów walidacji odbycie 75 godzin psychoterapii. Natomiast po zakończeniu szkolenia niezbędne jest kontynuowanie pracy własnej w formie superwizji.

Brak usankcjonowania prawnego ram kwalifikacji stanowi znaczny problem zarówno dla osób, które już pełnią rolę asystentów zdrowienia bądź chciałyby wykonywać ten zawód 
w przyszłości, jak i dla potencjalnych pracodawców, ponieważ szkolenia dla nich, a także nadawanie certyfikatów powinny się odbywać na podstawie zapisów tego dokumentu. Ponadto włączenie asystentów zdrowienia do Zintegrowanego Systemu Kwalifikacji umożliwiłoby ich zatrudnianie także poza systemem ochrony zdrowia (np. w instytucjach pomocy społecznej). Warto zaznaczyć, że obecnie w żadnym kraju europejskim asystent zdrowienia nie został wpisany na listę zawodów, więc prace legislacyjne w tym zakresie prowadzone w Polsce mają najbardziej zaawansowany charakter w Unii Europejskiej.

Zgodnie $z$ obowiązującym aktualnie prawem eksperci przez doświadczenie nie powinni mieć wglądu do dokumentacji osób w kryzysie (w tym dokumentacji medycznej). Kwestia ta powinna zostać prawnie uregulowana, przy czym warto pamiętać, że asystenci zdrowienia powinni mieć możliwość jakiejś formy dostępu do informacji medycznej pacjentów, ponieważ jest to konieczne do optymalizacji ich pomocowych działań.

\section{PIERWSZE DOŚWIADCZENIA Z WPROWADZANIEM ASYSTENTÓW ZDROWIENIA W POLSCE}

W ramach projektu Deinstytucjonalizacja szansq na dobrq zmianę. Projekt horyzontalny $(\mathrm{Nr}$ POWR.04.01.00-00-D20817), realizowanego przez Uniwersytet Kardynała Stefana Wyszyńskiego w Warszawie, przeprowadzono badanie ewaluacyjne dotyczące roli i funkcjonowania asystentów zdrowienia w środowiskowym modelu opieki psychiatrycznej. Poniżej przedstawione zostały główne wyniki ${ }^{4}$.

Rozmówcy, który wzięli udział w wywiadach, podkreślali, że samo ukończenie szkolenia nie powinno gwarantować ekspertom przez doświadczenie uzyskania zatrudnienia, ponieważ po przeprowadzonym kursie dla asystentów zdrowienia okazało się, że wiele osób nie przepracowało swojego kryzysu na tyle wnikliwie, by mogły pomagać innym. Niemniej jednak część uczestników przyznała, że choć nie czuje się gotowa do podjęcia pracy w roli asystenta zdrowienia, udział w szkoleniu był bardzo ważny z punktu widzenia ich rozwoju osobistego, ponieważ wyklarowała im się wizja tego, czym chcieliby się zająć w przyszłości. Można zatem sformułować tezę, że w kursach tych nie powinny brać udziału osoby będące w aktywnym kryzysie, a jedynie takie, które miały już możliwość przepracowania swojego doświadczenia. W Niemczech wymagane jest, by upłynął co najmniej rok od wystąpienia ostatnich objawów kryzysu. Ponadto asystenci zdrowienia powinni posiadać duże kompetencje komunikacyjne i cechować się empatią.

Wspólpraca $z$ asystentami zdrowienia, począwszy od etapu staży, może początkowo napotykać na opór ze strony profesjonalistów. W ramach staży każdy ekspert przez doświadczenie przebywał w Zespołach Leczenia Środowiskowego, na oddziale dziennym oraz w szpitalu całodobowym przez okres 1 miesiąca. Ponadto osoby te odbywały staże w Środowiskowych Domach Samopomocy. Sposób, w jaki asystenci zdrowienia zostali przyjęci w tych instytucjach, był w dużej mierze uzależniony od przygotowania specjalistów, za które

${ }^{4}$ Przeprowadzone badanie ewaluacyjne miało charakter jakościowy i objęło analizę dokumentacji gromadzonej w toku realizacji projektu, a także pogłębione wywiady indywidualne oraz zogniskowane wywiady grupowe w których wzięło udział łącznie 13 osób zatrudnionych w roli asystentów zdrowienia i osób zarządzających ich pracą w Środowiskowych Centrach Zdrowia Psychicznego. Dane empiryczne zebrane podczas wywiadów zostały uzupełnione o informacje, które zgromadzono podczas dwóch paneli eksperckich dotyczących asystentów zdrowienia, w których uczestniczyli przedstawiciele Środowiskowych Centrów Zdrowia Psychicznego w Wieliczce, Koszalinie, Warszawie-Bielanach, Nowym Targu, Centrów Zdrowia Psychicznego w Warszawie-Woli oraz Mokotowskim Centrum Zdrowia Psychicznego, reprezentanci Instytutu Psychiatrii i Neurologii w Warszawie i osoby reprezentujące organizacje pozarządowe zajmujące się wspieraniem Ex-In, jak również osób doświadczonych chorobami psychicznymi (Stowarzyszenie Asystentów Zdrowienia, Fundacja eFkropka). 
odpowiadali kierownicy danych placówek. Osoby zarządzające pracą asystentów zdrowienia podkreślały w wywiadach, że po upływie pewnego czasu, gdy zaczęły być widoczne efekty pracy asystentów zdrowienia, postawy personelu zaczęły ulegać zmianie. Obecnie doceniana jest inna perspektywa, którą eksperci przez doświadczenie wnoszą do zespołów terapeutycznych, toteż opór wobec tych osób w środowiskach profesjonalnych stopniowo maleje.

Jak już wspomniano, asystent zdrowienia jest nowym zawodem, który napotyka na liczne trudności o charakterze legislacyjnym, organizacyjnym oraz mentalnościowym (negatywne postawy wynikające ze stygmatyzacji i stereotypizacji osób z kryzysami psychicznymi). Biorąc pod uwagę trudności legislacyjne, najbardziej problematyczny jest brak przepisów regulujących dostęp asystentów zdrowienia do dokumentacji osób korzystających ze środowiskowego modelu opieki psychiatrycznej.

Wielu specjalistów kieruje się stereotypami i przejawia różne obawy związane $\mathrm{z}$ aktywnym udziałem ekspertów przez doświadczenie w procesie zdrowienia osób będących w kryzysie psychicznym. Środowisko psychologów obawia się udostępniania asystentom zdrowienia będących członkami zespołów terapeutycznych wrażliwych danych dotyczących pacjentów, a także wskazuje na potrzebę potwierdzenia, że asystenci znajdują się w stanie remisji objawów. Niektórzy profesjonaliści kwestionują też opis kwalifikacji asystentów zdrowienia jako mało precyzyjny oraz sygnalizują problem zbyt małej liczby etatów dla psychologów w systemie środowiskowej ochrony zdrowia psychicznego, co rzuca dodatkowe światło na ich opór wobec zatrudniania ekspertów przez doświadczenie, który może wynikać z poczucia zagrożenia i rywalizacji o miejsca pracy.

Część specjalistów, którzy nie mieli wcześniej okazji współpracować z asystentami zdrowienia, szczególnie psychologów, czuła się zagrożona ich obecnością w profesjonalnych zespołach, ponieważ postrzegali te osoby jako swoistą „konkurencję". Podkreślić należy, że organizacje branżowe psychologów, które konsultowały ramy kwalifikacji asystentów zdrowienia, wskazywały na ryzyko zajmowania przez nich etatów, które powinny być przeznaczone dla psychoterapeutów. Asystenci, którzy mogą poświęcać osobom w kryzysie więcej czasu, często wchodzą w bliskie relacje z nimi, stając się ich powiernikami i uzyskując informacje niedostępne dla specjalistów. Dodatkowo eksperci przez doświadczenie „stoją po stronie pacjentów", reprezentując ich potrzeby i interesy, co dla wielu profesjonalistów może być trudne do przyjęcia, ponieważ perspektywa tych osób nie była do tej pory dostatecznie uwzględniana.

Podczas gdy stosunek niektórych specjalistów opiera się na niedocenianiu roli asystentów zdrowienia czy wręcz ich dyskryminowaniu, część profesjonalistów utożsamia ich angażowanie $\mathrm{w}$ proces zdrowienia innych osób $\mathrm{z}$,wykorzystywaniem pacjentów”. Obie te postawy istotnie zagrażają krzewieniu idei „ekspertów przez doświadczenie” i wskazują na pilną potrzebę odpowiedniego przygotowywania zespołów pracowniczych do współpracy i włączania do swojego grona asystentów zdrowienia. Specjaliści muszą dobrze zrozumieć rolę tych osób w środowiskowym modelu opieki psychiatrycznej, a także dokładnie poznać zakres ich obowiązków i uprawnień.

$\mathrm{Na}$ trudności natury mentalnościowej, polegające na nieprzychylnych asystentom zdrowienia postawach ze strony profesjonalistów Ex-In natknęli się na etapie staży. Część specjalistów miała problemy z zaakceptowaniem tych osób, szczególnie w roli członków zespołu terapeutycznego. Relacje asystentów zdrowienia $z$ innymi pracownikami były w dużej mierze uzależnione od ich przygotowania (do współpracy z nimi). Szczególnie problematyczne okazały się staże, podczas których asystenci zdrowienia wspólpracowali z kadrą szpitali mającą z nimi wcześniej do czynienia w roli pacjentów. Niektórzy pracownicy byli na tyle zdezorientowani, że pytali np. o właściwe miejsce spożywania posiłków przez asystentów zdrowienia (w celu ich jednoznacznego przyporządkowania do grupy pacjentów bądź kadry).

Część profesjonalistów miała wątpliwości, czy asystenci zdrowienia poradzą sobie $\mathrm{w}$ trudnych sytuacjach i obawiała się wywołania u nich nawrotu kryzysu. Etap stażu bywał 
trudny dla obu stron - specjaliści dostrzegali zagubienie, przestrach i trudności w odnalezieniu się asystentów zdrowienia w nowej dla nich sytuacji, zaś stażyści czuli się dyskryminowani, gdy napotykali na opór ze strony kadry. $Z$ drugiej strony, niektórzy specjaliści przejawiali wobec asystentów zdrowienia postawy nadopiekuńcze, które również nie pozwalały im być „traktowanymi na równi” z innymi pracownikami. Niektórzy asystenci zdrowienia narażeni na mało przychylne postawy kadry oraz różne niepowodzenia reagowali zachowaniami lękowymi. Z kolei osoby, które były „przebodźcowane pozytywnie”, były narażone na popadnięcie w samozachwyt i utratę zdolności do krytycznego osądu. Obie te skrajne reakcje - pomimo tego, że nie są powszechne - wskazują na potrzebę uzyskania przez asystentów zdrowienia wsparcia, które pomogłoby im przepracować napotykane trudności. Szczególne ryzyko rodzi także duża wrażliwość oraz niska odporność asystentów zdrowienia na stres, która w połączeniu ze skrajnymi sytuacjami (np. próby samobójczej osoby w kryzysie) może wywołać załamanie i nawrót problemów psychicznych.

Sposób postrzegania asystentów zdrowienia przez współpracujących z nimi specjalistów może być też uzależniony od tego, czy dana osoba leczyła się wcześniej w obecnym miejscu pracy. Część osób uważa, że lepiej unikać takich sytuacji, choć czasami jest to niemożliwe ze względu na brak wyboru, szczególnie w mniejszych miejscowościach. W tych przypadkach ekspertom przez doświadczenie pozostaje zmiana miejsca zamieszkania i zatrudnienie się w placówce zlokalizowanej w innym mieście, co wiąże się z dodatkowymi wyzwaniami, na które nie wszyscy są gotowi. Gdy nie jest to możliwe, powrót pacjenta do danej instytucji w roli asystenta zdrowienia musi zostać przepracowany. Generalnie uważa się, że oddzielenie funkcji pacjenta i asystenta zdrowienia jest korzystne zarówno na etapie stażu, jak i późniejszego zatrudnienia.

$Z$ drugiej strony, znajomość specyfiki miejsca, w którym odbywało się leczenie, może być dla ekspertów przez doświadczenie cennym zasobem. Mogą oni czuć się bezpiecznie w znanym im szpitalu - znają personel tej placówki, różne oznaczenia, stosowane skróty i nazewnictwo. Asystenci, z którymi prowadzono wywiady i którzy uczestniczyli w panelu ekspertów, podkreślali, że jest to indywidualna sprawa i każdy z nich powinien mieć możliwość wyboru miejsca zatrudnienia. Nie można z góry przesądzać, jak potoczy się ich współpraca $z$ kadrą danej instytucji, natomiast bardzo ważne jest wyznaczenie jej granic tego, co eksperci przez doświadczenie mogą robić, a czego nie, co wchodzi w zakres ich obowiązków, a co poza nie wykracza. Takie ustalenia dają poczucie bezpieczeństwa wszystkim stronom - asystentom zdrowienia, ich podopiecznym i profesjonalistom - a także zapobiegają pokusie zastępowania specjalistów, na którą narażeni są eksperci przez doświadczenie. Należy zaznaczyć, że czasami granice te mogą być dość płynne, szczególnie w sytuacji, gdy pełnią oni rolę terapeutów zajęciowych, co może rodzić pewne trudności.

Kolejny rodzaj problemów, na które wskazywali zarówno asystenci zdrowienia, jak i kadra zarządzająca, miał charakter organizacyjny. Znacznym utrudnieniem na etapie staży była dla asystentów zdrowienia konieczność szybkiego przyswojenia dużej ilości informacji, szczególnie w połączeniu z brakiem czasu na rozmowę ze specjalistami, którzy byli zaangażowani w wykonywanie swoich obowiązków. W tej sytuacji musieli oni do wielu rzeczy dochodzić samodzielnie, np. rozszyfrowywać różne skróty, oznaczenia i terminy. Trudność ta wiąże się z potrzebą uczestnictwa asystentów zdrowienia w różnych kursach i szkoleniach, które $\mathrm{w}$ istotnym stopniu wspierałyby ich pracę.

Dzięki asystentom zdrowienia możliwe jest pogłębianie wiedzy na temat czynników, które korzystnie wpływają na proces zdrowienia i przeciwdziałają występowaniu kryzysów. Eksperci przez doświadczenie przyczyniają się do rozwijania wiedzy przekazywanej profesjonalistom w ich procesie kształcenia i jej lepszego rozumienia, a także wypracowywania nowych metod leczenia oraz tworzenia innowacyjnych usług medyczno-społecznych.

Asystenci zdrowienia wzmacniają proces zdrowienia poprzez podtrzymywanie zachodzących zmian u osób z doświadczeniem kryzysu (ustępowanie objawów, zmianę leków 
na słabsze), motywowanie ich do aktywności społecznej i zawodowej, podejmowania różnych ról społecznych, powrotu do szkoły lub pracy bądź poszukiwania nowych możliwości $\mathrm{w}$ tym zakresie. Utrwaleniu pozytywnych zmian służy ścisła współpraca z osobami w kryzysie przez dłuższy czas oraz oddziaływanie na ich dobrostan za pośrednictwem rodzin lub bliskich. Eksperci przez doświadczenie dają tym osobom nadzieję na wyjście z kryzysu, a następnie wykorzystania go jako zasobu w dalszym życiu. Asystenci zdrowienia wspierają też rozwój sieci społecznych poprzez nakłanianie rodzin osób w kryzysie do zrzeszania się i zawiązywania stowarzyszeń działających na rzecz osób z trudnościami psychicznymi. Takie ruchy społeczne ciągle jeszcze są w Polsce nowością ze względu na silną stereotypizację oraz tabu choroby psychicznej, jednak powoli te postawy zaczynają się zmieniać. Dalszy rozwój struktur asystentów zdrowienia w środowiskach lokalnych wynika $\mathrm{z}$ potrzeby wzajemnego wspierania się i zwalczania stereotypów. W ten sposób działają oni jednocześnie na rzecz własnej społeczności - reprezentując osoby z trudnościami psychicznymi, angażują się w reformę systemu opieki psychiatrycznej w Polsce i podejmują aktywności mające na celu przeciwdziałanie stygmatyzowaniu osób z doświadczeniem kryzysu psychicznego.

Wraz ze specjalistami asystenci zdrowienia mogą zajmować się również edukacją w ramach działań profilaktycznych, wnosząc do wiedzy przekazywanej przez specjalistów treści oparte na własnych doświadczeniach. W ten sposób mogą przyczynić się do zmniejszenia stygmatyzacji osób z problemami psychicznymi, walczyć z zakorzenionymi w społeczeństwie stereotypami oraz wdrażać dobre praktyki w instytucjach świadczących usługi na rzecz zdrowia psychicznego oraz prowadzących edukację w tym zakresie.

Działania profilaktyczne, w których uczestniczą asystenci zdrowienia, mają o wiele większą „,iłę rażenia”. Wiarygodność tych osób i ich umiejętność „trafiania do serca” sprawiają, że edukowanie społeczeństwa jest znacznie bardziej efektywne. Mogą oni wspierać odbiorców profilaktyki, podobnie jak swoich podopiecznych, poprzez wskazywanie, jak rozpoznać pierwsze sygnały kryzysu, co robić, by poprawić swój nastrój oraz jak sobie pomóc w trudnej sytuacji. Uczą inne osoby, jak tworzyć własny plan kryzysowy i wskazują, gdzie w razie potrzeby można szukać pomocy. Uczestnicząc w działaniach profilaktycznych asystenci zdrowienia występują $\mathrm{w}$ roli edukatorów, współpracując $\mathrm{z}$ różnymi instytucjami oświatowymi (szkołami, uczelniami), a także podmiotami związanymi z pomocą psychiatryczną i psychologiczną.

Nie dysponujemy danymi, które świadczyłyby o tym, w jaki sposób asystenci zdrowienia są postrzegani przez środowiska lokalne czy ogół społeczeństwa, który najprawdopodobniej nie jest świadomy istnienia tych osób w systemie ochrony zdrowia psychicznego. Informacje zebrane podczas wywiadów wskazują na to, że relacje pomiędzy asystentami zdrowienia a ich podopiecznymi mogą układać się w zróżnicowany sposób, który wpływa na percepcję Ex-In. Niektóre osoby w kryzysie nie chcą rozmawiać $\mathrm{z}$ nikim innym poza asystentami zdrowienia, którzy czasami pracują jednocześnie z członkami rodziny swoich klientów. Bliscy tych osób często czują się zagubieni w nowej i trudnej dla nich sytuacji, więc asystenci zdrowienia stanowią istotne wsparcie, umożliwiając rodzinie lepsze zrozumienie osoby przechodzącej przez kryzys oraz dają nadzieję na pozytywne rozwiązanie obecnych trudności. Niemniej jednak część rodzin może mieć wobec asystentów zdrowienia nadmierne oczekiwania, licząc na uzyskanie gotowej „recepty”, dzięki której ich problemy samoistnie znikną, a osoba w kryzysie w pełni wyzdrowieje.

Warto podkreślić, że kwestia indywidualnej i społecznej percepcji ekspertów przez doświadczenie wymaga dalszych badań. Ramy zadań realizowanych przez asystentów zdrowienia powinny raczej wyznaczać działania, których - z uwagi na wymagane kwalifikacje i uprawnienia - osoby te nie mogą podejmować. Dlatego ważne jest czuwanie nad tym, by wspierali oni specjalistów, nie wchodząc jednocześnie w ich role, tym bardziej że mają do odegrania własną, gdyż profesjonaliści nie są w stanie zastąpić ekspertów przez doświadczenie. 
Wydaje się zatem, że asystenci zdrowienia powinni raczej pełnić uniwersalną rolę niż realizować ściśle wyznaczone zadania. Na początku współpracy należy zaoferować im wachlarz różnych możliwości, który pokaże potencjał tych osób. Warto podkreślić ich niewątpliwie mocne strony, którymi są:

- wiarygodność i autentyczność, które uzyskują dzięki doświadczeniu kryzysu i dzieleniu się swoimi przeżyciami, a także brakowi limitów czasu przeznaczonego na spotkania z osobami w kryzysie - „poświęcanie im tyle czasu, ile potrzebują” (co nie jest możliwe w przypadku specjalistów),

- możliwość nawiązania kontaktu i rozpoczęcia współpracy z osobami przebywającymi na oddziałach szpitalnych, a następnie kontynuowania tego wsparcia w środowisku lokalnym,

- branie aktywnego udziału w modelowaniu nowych postaw społecznych wobec kryzysu psychicznego oraz osób borykających się z trudnościami psychicznymi, a także ich leczenia w środowisku lokalnym - przeciwdziałanie tabu i stygmatyzacji czy możliwość przekucia doświadczenia kryzysu w wartościowy potencjał, na bazie którego można odzyskać kontrolę nad własnym życiem - niezależność, poczucie podmiotowości i samorealizacji,

- prowadzenie współpracy z różnymi instytucjami systemu opieki psychiatrycznej oraz wsparcia społecznego, w zależności od potrzeb podopiecznych; inicjowaniu działań zarówno o charakterze środowiskowym, jak i zasięgu ogólnopolskim sprzyja również ścisła kooperacja z organizacjami pozarządowymi (NGO), szczególnie takimi, które zrzeszają osoby z doświadczeniem kryzysu i ich bliskich.

Współpraca $z$ asystentami zdrowienia mimo wielu zalet niesie ze sobą także pewne zagrożenia, które powinny zostać zniwelowane. Mowa tu o omówionych powyżej ryzykach, takich jak:

- pokusa wchodzenia w rolę specjalisty, a także przekraczania własnych granic oraz zatracania się w pracy,

- duże obciążenie psychiczne spowodowane charakterem pracy i związane z nią ryzyko doświadczania nadmiernego stresu oraz destabilizacji i ponownego wejścia w kryzys,

- negatywne postawy i opór przejawiane wobec asystentów zdrowienia przez specjalistów (szczególnie psychologów, którzy postrzegają obecność ekspertów przez doświadczenie w zespołach terapeutycznych jako zagrożenie dla własnych kompetencji, zadań zawodowych i relacji z osobami w kryzysie),

- sztywność i hierarchiczność struktur w instytucjach, z którymi asystenci zdrowienia mają współpracować (np. szpitale, OPS-y), w tym długotrwały proces „odnajdowania” się w tych podmiotach spowodowany m.in. brakiem znajomości ich struktury, stosowanej terminologii i oznaczeń (np. poszczególnych oddziałów w szpitalach),

- nieprzygotowanie kadr ww. placówek do współpracy z asystentami zdrowienia,

- brak zatwierdzenia ram kwalifikacji asystentów zdrowienia skutkujący brakiem dostępu do nieodpłatnych szkoleń oraz oferowaniem przez rynek komercyjnych kursów opartych na dowolnych programach,

- niejasna sytuacja prawna w zakresie dostępu asystentów zdrowienia do dokumentacji (medycznej) pacjentów.

\section{WNIOSKI I REKOMENDACJE}

W celu rozwiązania omówionych powyżej problemów na podstawie przeprowadzonego badania ewaluacyjnego w ramach projektu Deinstytucjonalizacja szansq na dobra zmianę. Projekt horyzontalny (Nr POWR.04.01.00-00-D20817), realizowanego przez Uniwersytet 
Kardynała Stefana Wyszyńskiego w Warszawie, można zarekomendować różne rozwiązania. Biorąc pod uwagę kształcenie asystentów zdrowienia, wskazane jest dopracowanie zasad rekrutacji kandydatów na kurs (np. przepracowane doświadczenie kryzysu w formie terapii własnej, premiowanie wcześniejszego zaangażowania społecznego np. w wolontariat, weryfikacja oczekiwań wobec szkolenia). Należy rozważyć kontynuowanie kursów dla asystentów zdrowienia $\mathrm{w}$ formule dwustopniowej - w podziale na szkolenie wstępne, ogólnodostępne o charakterze rozwojowym (trwające np. 7 miesięcy), a następnie kurs zaawansowany, profesjonalny (np. 5-miesięczny) i skierowany do osób, które chcą pracować jako asystenci zdrowienia. Staże dla asystentów zdrowienia powinny być obligatoryjnym elementem kształcenia tych osób, ponieważ umożliwiają im zweryfikowanie w praktyce posiadanych predyspozycji i nabytych w czasie kursu kompetencji. Warto także zadbać o zwiększenie dostępności kursów przygotowawczych dla tych osób poprzez zatwierdzenie ram kwalifikacji i certyfikacji, które umożliwi ujednolicenie tych szkoleń, a także ich dofinansowanie ze środków publicznych, w tym unijnych (w ramach Regionalnych Programów Operacyjnych). Kursy dla asystentów zdrowienia powinny być realizowane w całym kraju, zapewniając możliwość kształcenia się ekspertów przez doświadczenie blisko miejsca ich zamieszkania. Konieczne jest także poszerzenie bazy kadrowej i wypracowanie ścieżki kształcenia trenerów, którzy będą prowadzić szkolenia dla asystentów zdrowienia, tj. realizowanie kursów dla trenerów (train the trainer).

Dobrą praktyką wartą upowszechnienia będzie także obligatoryjne wyznaczenie opiekunów staży asystentów zdrowienia w rożnych instytucjach, a także przygotowanie ich kadr do współpracy z Ex-In. Wskazane jest pozostawienie asystentom zdrowienia decyzji dotyczącej wyboru miejsca pracy (preferowane są podmioty, w których te osoby wcześniej się nie leczyły, choć jest to kwestia indywidualna). W procesie wdrożenia asystentów zdrowienia do zawodu należy zapewnić mentoring, który będzie wspierał te osoby w odnalezieniu się w nowym środowisku pracy i rozwiązywaniu bieżących problemów zawodowych. Asystenci zdrowienia powinni być objęci ustawicznym kształceniem w zakresie np. ochrony danych osobowych, psychoedukacji (np. rodzajów zaburzeń/chorób), kompetencji inter- i intrapersonalnych (np. radzenia sobie ze stresem, dystansowania się, asertywności) oraz pracy metodą Otwartego Dialogu. Ponadto należy objąć asystentów zdrowienia wsparciem superwizyjnym zarówno na etapie szkoleń, jak i staży oraz pracy (nie tylko w formie superwizji prowadzonej dla zespołów terapeutycznych, ale także ukierunkowanej wyłącznie na potrzeby asystentów zdrowienia). Ważnym wsparciem dla tych osób będzie też organizowanie cotygodniowych spotkań oraz grup wsparcia dla asystentów zdrowienia. $Z$ punktu widzenia realizowanych zadań zawodowych pomocne będzie opracowanie kodeksu czy zasad pracy asystentów zdrowienia, jak również procedur postępowania w określonych sytuacjach (np. pierwszych oznak wchodzenia w kryzys), precyzyjne określenie zakresu obowiązków (zapobiegające wchodzeniu w kompetencje specjalistów), a także praca w parach w przypadku instytucji (np. szpitali lub ośrodków pomocy społecznej), które dotąd nie zetknęły się z ideą asystentów zdrowienia. Biorąc pod uwagę perspektywę pracodawcy, w przypadku asystentów zdrowienia warto również uwzględnić potrzebę częstszych zwolnień lekarskich oraz niekorzystanie $\mathrm{z}$ opieki medycznej w miejscu pracy.

Kluczową kwestią z punktu widzenia upowszechniania zawodu asystenta zdrowienia oraz pełnionej przez niego roli $\mathrm{w}$ systemie ochrony zdrowia psychicznego $\mathrm{w}$ Polsce jest prowadzenie kampanii społecznych (z udziałem asystentów zdrowienia) służących przełamywaniu tabu i stereotypów, a także zagwarantowanie środków na prowadzenie akcji informacyjnych, które posłużą nagłaśnianiu korzyści wynikających z działań tych osób i wzmacnianiu ich widoczności w środowisku lokalnym. 


\section{UWAGI}

Artykuł został przygotowany na podstawie raportu ewaluacyjnego pn. Rola i funkcjonowanie Asystentów Zdrowienia w modelu Środowiskowego Centrum Zdrowia Psychicznego, który został opracowany w 2020 roku w ramach projektu pt. Deinstytucjonalizacja szansq na dobrq zmianę. Projekt horyzontalny (Nr POWR.04.01.00-00-D20817), wspólfinansowanego przez Unię Europejską w ramach Europejskiego Funduszu Społecznego, realizowanego przez Uniwersytet Kardynała Stefana Wyszyńskiego w Warszawie.

\section{BIBLIOGRAFIA}

Basset, T., Faulkner, A., Repper, J., Stamou, E. (2010). Lived experience leading the way: Peer support in mental health. Londyn: Together UK.

Bronowski, P., Chotkowska, K., Bednarzak, J. (2016). Ruch samopomocowy osób z doświadczeniem choroby psychicznej - Grupa Wsparcia TROP. Postępy Psychiatrii i Neurologii, 25(3), 190-195.

Cechnicki, A., Liberadzka, A. (2012). Nowe role osób chorujących psychicznie w procesie leczenia i zdrowienia. Psychiatria Polska, 16(6), 995-1005.

Crane, D. A., Lepicki, T., Knudsen, K. (2016). Unique and common elements of the role of peer support in the context of traditional mental health services. Psychiatric Rehabilitation Journal, 39(3), 282-288. https://doi.org/10.1037/prj0000186

Davidson, L., Bellamy, C., Guy, K., Miller, R. (2012). Peer support among persons with severe mental illnesses: A review of evidence and experience. World Psychiatry: Official Journal of the World Psychiatric Association (WPA), 11(2), 123-128. https://doi.org/10.1016/j.wpsyc.2012.05.009

Davidson, L., Chinman, M., Sells, D., Rowe, M. (2006). Peer support among adults with serious mental illness: A report from the field. Schizophrenia Bulletin, 32(3), 443-450. https://doi.org/10.1093/schbul/sbj043

Delman, J., Vorhies Klodnick, V. (2017). Effectively employing young adult peer providers: A toolkit. Boston: The Learning and Working Center Transitions RTC.

Kaczmarczyk, S., Kowalska-Dąbrowska, M., Panek, M., Walter, B., Starzomska, M., Rosińska, P., Jastrzębski, J. (2019). Asystent Zdrowienia. Model programu szkoleniowego i nowego zawodu. Kraków: Fundacja Wspierania Rozwoju Społecznego Leonardo.

Mokrzycka-Markowska, M., Drozdowicz, E., Nasierowski, T. (2015). Deinstytucjonalizacja psychiatrii włoskiej - przebieg i skutki. Część II. Skutki deinstytucjonalizacji. Psychiatria Polska, 49(2), 403-412.

Mowbray, C., Moxley, D., Collins, M. (1998). Consumers as mental health providers: First-person accounts of benefits and limitations. The Journal of Behavioral Health Services \& Research, 25(4), 397-411. https://doi.org/10.1007/BF02287510

Pickett, S. A., Diehl, S. M., Steigman, P. J., Prater, J. D., Fox, A., Shipley, P., ... Cook, J. A. (2012). Consumer empowerment and self-advocacy outcomes in a randomized study of peer-led education. Community Mental Health Journal, 48(4), 420-430. https://doi.org/10.1007/s10597012-9507-0

Salzer, M. (1997). Consumer empowerment in mental health organizations: Concept, benefits, and impediments. Administration and Policy in Mental Health, 24(5), 425-434. https://doi.org/10.1007/BF02042724

Salzer, M., Shear, S. L. (2002). Identifying consumer-provider benefits in evaluations of consumer-delivered services. Psychiatric Rehabilitation Journal, 25(3), 281-288. https://doi.org/10.1037/h0095014

Sherman, P. S., Porter, R. (1991). Mental health consumers as case management aides. Hospital \& Community Psychiatry, 42(5), 494-498. https:// doi.org/10.1176/ps.42.5.494

Solomon, P. (2004). Peer support/peer provided services underlying processes, benefits, and critical ingredients. Psychiatric Rehabilitation Journal, 27(4), 392-401. https://doi.org/10.2975/27.2004.392.401

Utschakowski, J. (2012). Implementation of peer-experts in mental health practice. Amsterdam: HMP van Haaster.

Zadrożna, A. (2019). Grupy samopomocowe osób chorujących psychicznie. Niepełnosprawność-zagadnienia, problemy, rozwiązania, 3(32), 63-79. 